\title{
High prevalence of methicillin resistant Staphylococcus aureus in the surgical units of Mulago hospital in Kampala, Uganda
}

David P Kateete ${ }^{1}$, Sylvia Namazzi ${ }^{1,2}$, Moses Okee ${ }^{1}$, Alfred Okeng ${ }^{1}$, Hannington Baluku', Nathan L Musisi ${ }^{2}$, Fred A Katabazi ${ }^{1}$, Moses L Joloba ${ }^{1}$, Robert Ssentongo ${ }^{3}$ and Florence C Najjuka ${ }^{1 *}$

\begin{abstract}
Background: There is limited data on Methicillin resistant Staphylococcus aureus (MRSA) in Uganda where, as in most low income countries, the routine use of chromogenic agar for MRSA detection is not affordable. We aimed to determine MRSA prevalence among patients, healthcare workers (HCW) and the environment in the burns units at Mulago hospital, and compare the performance of CHROMagar with oxacillin for detection of MRSA.

Results: One hundred samples (from 25 patients; 36 HCW; and 39 from the environment, one sample per person/ item) were cultured for the isolation of Staphylococcus aureus. Forty one S. aureus isolates were recovered from 13 patients, $13 \mathrm{HCW}$ and 15 from the environment, all of which were oxacillin resistant and mecA/femA/nuc-positive. MRSA prevalence was 46\% (41/89) among patients, HCW and the environment, and 100\% (41/41) among the isolates. For CHROMagar, MRSA prevalence was 29\% (26/89) among patients, HCW and the environment, and 63\% (26/41) among the isolates. There was high prevalence of multidrug resistant isolates, which concomitantly possessed virulence and antimicrobial resistance determinants, notably biofilms, hemolysins, toxin and ica genes. One isolate positive for all determinants possessed the bhp homologue which encodes the biofilm associated protein (BAP), a rare finding in human isolates. SCCmec type I was the most common at 54\% prevalence (22/41), followed by SCCmec type V (15\%, 6/41) and SCCmec type IV (7\%, 3/41). SCCmec types II and III were not detected and 10 isolates (24\%) were non-typeable.
\end{abstract}

Conclusions: Hyper-virulent methicillin resistant Staphylococcus aureus is prevalent in the burns unit of Mulago hospital.

\section{Background}

There is a global outbreak of Methicillin resistant Staphylococcus aureus (MRSA) infections, particularly in industrialized countries [1]. However, there is limited data on MRSA prevalence in Uganda, where $10 \%$ of the surgical procedures become septic with $S$. aureus being the most frequent pathogen isolated [2-4]. Ojulong et al. 2009 determined the prevalence of MRSA in patients with post-operative surgical wound infections in the surgical wards of Mulago hospital in Kampala, Uganda [5], but the distribution of isolates among healthcare workers $(\mathrm{HCW})$ and the environment was

\footnotetext{
* Correspondence: najjuka2002@yahoo.com

'Department of Medical Microbiology, School of Biomedical Sciences,

Makerere University College of Health Sciences, Kampala, Uganda

Full list of author information is available at the end of the article
}

not determined. Here, we aimed to determine MRSA prevalence among patients, $\mathrm{HCW}$ and the environment in the burns units at Mulago hospital, and compare the performance of CHROMagar with oxacillin for detection of MRSA (since the routine use of chromogenic agar is usually not affordable in most low income settings).

\section{Methods}

\section{Study setting and sampling}

This cross-sectional study was performed during November, 2009 and February, 2010 in the two surgical units specializing in the treatment of patients with burns at Mulago national referral hospital in Kampala, Uganda. Ethical approval was obtained from the Department of Surgery, Mulago Hospital, and the Research and Ethics Committee of Makerere University College

\section{() Biomed Central}

(c) 2011 Najjuka et al; licensee BioMed Central Ltd. This is an open access article distributed under the terms of the Creative Commons Attribution License (http://creativecommons.org/licenses/by/2.0), which permits unrestricted use, distribution, and reproduction in any medium, provided the original work is properly cited. 
of Health Sciences. Informed consent was obtained from patients and HCW. Patients and HCW enrolled had stayed in the hospital units for at least 72 hours. HCW included doctors, nurses and nursing aids that had direct involvement with patients. For the environment, surfaces of frequently handled items (door handles, sinks, surgical trays, beds and table surfaces) were swabbed, as well as air samples on settle plates (with blood agar). For patients, wounds or nostrils were swabbed while for HCW, hands or nostrils were swabbed. One hundred samples (one sample per person or item) from 25 patients, $36 \mathrm{HCW}$ and 39 items (including air settle plates) were obtained using sterile swabs and transported to the laboratory for culture in tubes containing Amies transport medium (Biolab, Budapest, Hungary).

\section{Cultures and drug susceptibility testing (DST)}

Swabs were cultured on blood agar and Mannitol salt agar at $37^{\circ} \mathrm{C}$ for 24 hours, ensuring growth of distinct colonies. The predominant colony type per sample was selected, and $S$. aureus was identified to species level microbiologically as previously described [6]. Drug susceptibility testing (erythromycin, $15 \mu \mathrm{g}$; vancomycin, $30 \mu \mathrm{g}$; gentamicin, $10 \mu \mathrm{g}$; oxacillin, $1 \mu \mathrm{g}$; tetracycline, $30 \mu \mathrm{g}$; chloramphenicol, $30 \mu \mathrm{g}$; penicillin, 10 units; and sulphamethoxazole-trimethoprim, 1.25/23.15 $\mu \mathrm{g}$ ) was performed with the disc diffusion method (Biolab inc, Budapest, Hungary). Isolates resistant to erythromycin were screened for the macrolide-lincosamide and streptrogramin $\mathrm{B}\left(\mathrm{MLS}_{\mathrm{B}}\right)$ phenotype. MRSA was identified based on oxacillin resistance following standard procedures [7], and confirmed by PCR detection of the $m e c A$ gene. For comparison, oxacillin resistant-mec $A$ positive isolates were further screened for growth on CHROMagar (BD diagnostics, Sparks, USA).

\section{SCCmec genotyping}

Staphylococcus Cassette Chromosomal mec (SCCmec) genotyping was performed in a multiplex PCR protocol described by Boye et al, 2007 (see additional file 1 for primers and PCR conditions) [8]. The SCCmec types were determined based on the banding patterns upon agarose gel electrophoresis of the amplicons [8]. Isolates with no visible bands were classified as non-typeable [8].

\section{Detection of virulence determinants Biofilms}

Biofilms were detected with the microtiter plate method [9] and the biofilm unit calculated according to Amaral et al. [10]. Briefly, assays were performed in triplicates in tryptic soya broth (TSB) with $1 \%$ glucose in 96-well polystyrene flat-bottom tissue culture plates. Isolates were incubated at $37^{\circ} \mathrm{C}$ overnight with gentle shaking and standardized to $\mathrm{OD}_{600}=0.005$ with normal saline. Then, $50 \mu \mathrm{l}$ of standardized cells mixed with $150 \mu \mathrm{l}$ $\mathrm{TSB} / 1 \%$ glucose were incubated at $37^{\circ} \mathrm{C}$ for $17 \mathrm{hr}$. After washing three times with sterile water and staining with crystal violet for 15 minutes, cells were washed again and incubated at room temperature for $1 \mathrm{hr}$ in $95 \%$ ethanol. Then, biofilms were measured with a spectrophotometer at $\mathrm{OD}_{570}$. The biofilm unit (BU) was calculated using negative control values with the formula $A_{1}$ / $A_{2}$, where $A_{1}$ is the test value while $A_{2}$ is the negative control value. Isolates with $\mathrm{BU}>2 \times$ the negative control value were considered biofilm producers and were classified as: weak, $0.182<\mathrm{BU}<0.364$; moderate, $0.364<$ $\mathrm{BU}<0.728$; strong, $\mathrm{BU}>0.728$ [10]. The biofilm forming S. epidermidis RP62A and its non-biofilm forming variant (ATCC 12228) were used as controls.

Virulence and antimicrobial resistance genes

Molecular assays for the detection of virulence associated genes, ica (intercellular adhesion); cna (collagen adhesion [11]); hemolysins ( hla, hlb, hld, hlg [12]); sdrE (serine-aspartate repeat protein E [11]); PVL (PantonValentine leukocidin [13]); and S. aureus super-antigenic toxins (tst, toxic shock syndrome toxin $[12,14]$ and sea, staphylococcal enterotoxin A $[12,14]$ ) were performed with primers and conditions described in literature (also see additional file 1). To detect genes encoding aminoglycoside-modifying enzymes (AMEs) [15], PCR on aac (6')-Ie-aph(2")-Ia (bifunctional aminoglycoside-6-N-acetyltransferase/2"-O- phosphoryltransferase), aph(3')-IIIa (aminoglycoside-3'-O-phosphoryltransferase III) and ant (4')-Ia (aminoglycoside-4'-O-nucleotidyltransferase I) was performed. Presence of mecA (the molecular determinant of methicillin resistance), $v a n A / v a n B 1$ (encode vancomycin resistance variants) and bla $Z$ (encodes $\beta$ lactamase) was also determined by PCR. For mecA genotyping, methicillin resistant S. aureus (MRSA-252) and methicillin sensitive $S$. aureus (MSSA, ATCC 29213) were used as positive and negative controls, respectively. For analysis, amplicons were electrophoresed on $1 \%$ agarose gels in TBE (Tris borate and EDTA) and representative samples sequence-confirmed. The data was analyzed with GraphPad Prism 5 software and presented graphically. Primers and PCR conditions are described in additional file 1 . To minimize cross-contamination, DNA extraction and PCR-amplifications were performed in molecular laboratories that are separate from the clinical microbiology laboratory where cultures were grown. The PCR laboratory has designated sections for preamplification, amplification and post-amplification.

\section{Results}

Gram positive isolates grew from 62 samples but 11 were lost (five from $\mathrm{HCW}$, four from patients and two from the environment), leaving 51 samples that were completely 
processed. From these, S. aureus grew from 41 samples: 14 from patients $(67 \%, 14 / 21$; 4 from nostrils and 10 from wounds), 13 from HCW (42\%, 13/31; 5 from nostrils and 8 from finger swabs), and 14 from the environment (38\%, $14 / 37$, see Table 1). Each isolate grew from a distinct sample per person or item. Thus, the prevalence of $S$. aureus in the burns unit was $46 \%(41 / 89)$, (Table 1 ).

All the 41 isolates were sensitive to vancomycin; conversely, all the isolates were oxacillin resistant and $m e c A / n u c / f e m A$-positive (implying they were $S$. aureus), revealing an MRSA prevalence of $46 \%(41 / 89)$ in the burns unit (i.e., among patients, HCW and environment) and 100\% (41/41) among isolates (see table 1). SCCmec type I was the most common at $54 \%$ prevalence $(22 / 41)$, followed by SCCmec type V $(15 \%, 6 / 41)$ and SCCmec type IV (7\%,3/41). SCCmec types II and III were not detected and 10 isolates $(24 \%)$ were nontypeable (see table 1). For CHROMagar, only 26 isolates grew with the characteristic mauve color indicative of MRSA, revealing a prevalence of $29 \%$ in the unit (i.e., among patients, HCW and environment) and 63\% (26/ 41) among isolates.

Overall, 26 six isolates $(63 \%, 26 / 41)$ MDR with the commonest pattern being resistance to $\beta$-lactams, sulphamethoxazole-trimethoprim (SXT) and tetracycline. Indeed, resistance to penicillin, tetracycline and SXT was high $(93 \%, 38 / 41 ; 68 \%, 28 / 41$ and $66 \%, 27 / 41$ prevalence, respectively); resistance to penicillin correlated with the high prevalence of blaZ gene (93\%, 38/41, see Figure 1). Conversely, erythromycin, gentamicin and chloramphenicol resistance was relatively low $(29 \%, 12 / 41 ; 20 \%, 8 / 41$ and $20 \%, 8 / 41$ prevalence respectively) and correlated with that of the AMEs encoding genes: $\operatorname{aac}\left(6^{\prime}\right)-I e-\operatorname{aph}\left(2^{\prime \prime}\right)-I a$ (61\%, 25/41); aph(3')-IIIa (34\%, 14/41); and ant(4')-Ia $(20 \%, 10 / 20)$, which are associated with aminoglycoside resistance [16]. With the exception of one isolate, all the isolates possessing AMEs encoding genes were concomitantly ica-positive. Additionally, three isolates resistant to erythromycin gave a positive D-test indicating possible cross-resistance to macrolide-lincosamide-streptogramin $\left(\mathrm{MLS}_{\mathrm{B}}\right)$ antibiotics in this setting [17].
Most isolates were strongly biofilm-positive (100\%, $41 / 41$, see Figure 1 ) and nearly all had the ica genes (93\%, $38 / 41$, with only three testing negative); only one of the two ica-negative isolates was MDR. Furthermore, all the isolates exhibited $\beta$-hemolysis on blood agar $(100 \%, 41 / 41)$ and this correlated with the high prevalence of the genes encoding hemolysins: hla, 100\% (41/41); hld, 100\% $(41 / 41)$; and $h l g, 61 \%(25 / 41))$. Many isolates possessed additional virulence genes: sea, 85\% (35/41); sdrE, 83\% (34/41); and $P V L, 73 \%$ (30/41), while cna and tsst were less prevalent (29\%, 12/41 and 10\%, $4 / 41$ respectively). Thirty four $(83 \%, 34 / 41)$ isolates were $i c a / s d r E$-positive; 33 $(80 \%, 33 / 41)$ ica/sea-positive; 28 (68\%, 28/41) ica/PVLpositive; 23 (56\%, 23/41) ica/hlg-positive and three (7\%, $3 /$ 41) ica/tsst-positive. All the $12(29 \%, 12 / 41)$ cna-positive isolates were also ica-positive. Interestingly, an isolate positive for all the determinants studied possessed the homologue of the $b h p$ gene, which encodes the biofilm associated protein (BAP); this is rarely detected in human isolates but frequently detected in staphylococci causing bovine mastitis [18]. This bhp-positive isolate was MDR and negative for only three determinants, tst, aph(3')-IIIa and ant(4')-Ia, conforming to its susceptibility to erythromycin/gentamicin. Detailed analyses for the virulence and antimicrobial resistance determinants are provided in additional file 2 .

\section{Discussion}

In this study, high prevalence of MDR-MRSA was found in the burns unit of Mulago hospital, predisposing patients to infection with intractable isolates and underscoring the need for improved infection control practices in this setting. Ojulong et al 2009, reported a relatively lower prevalence (31.6\%) from the general surgery ward, possibly because this earlier study determined MRSA infections in only patients with post-operative surgical wound infections [5]. Although data are still limited, there are emerging reports of prevalent MRSA infections in sub-Saharan Africa [19].

CHROMagar, generally considered more efficient at detecting MRSA than oxacillin discs [20] was inefficient

Table 1 MRSA prevalence (\%) and SCCmec types among isolates from the burns units at Mulago hospital

\begin{tabular}{|c|c|c|c|c|c|c|c|c|c|c|c|c|}
\hline \multirow[b]{2}{*}{ Sample source $(n=89)$} & \multirow[b]{2}{*}{ S. aureus $^{1}$} & \multirow[b]{2}{*}{$\operatorname{mec} A$} & \multicolumn{2}{|c|}{ Oxacillin disc } & \multicolumn{2}{|c|}{ CHROMagar } & \multicolumn{6}{|c|}{ SCCmec types } \\
\hline & & & MSSA & MRSA & MSSA & MRSA & I & II & III & IV & V & NT \\
\hline $\begin{array}{l}\text { Patients } \\
(n=21)\end{array}$ & 14 & 14 & ND & 14 & 4 & 10 & 8 & ND & ND & 3 & 1 & 2 \\
\hline $\begin{array}{l}\mathrm{HCW} \\
(\mathrm{n}=31)\end{array}$ & 13 & 13 & ND & 13 & 4 & 9 & 8 & ND & ND & ND & 3 & 2 \\
\hline $\begin{array}{l}\text { Environment } \\
(\mathrm{n}=37)\end{array}$ & 14 & 14 & ND & 14 & 7 & 7 & 6 & ND & ND & ND & 2 & 6 \\
\hline Prevalence & $\begin{array}{l}46 \\
(41 / 89)\end{array}$ & $\begin{array}{l}100 \\
(41 / 41)\end{array}$ & & $\begin{array}{c}46 \\
(41 / 89)\end{array}$ & $\begin{array}{c}17 \\
(15 / 89)\end{array}$ & $\begin{array}{c}29 \\
(26 / 89)\end{array}$ & $\begin{array}{c}54 \\
(22 / 41)\end{array}$ & - & - & $\begin{array}{c}7 \\
(3 / 41)\end{array}$ & $\begin{array}{c}15 \\
(6 / 41)\end{array}$ & $\begin{array}{c}24 \\
(10 / 41)\end{array}$ \\
\hline
\end{tabular}

${ }^{1}$ Isolates per sample; ND, Not detected; HCW, healthcare worker; NT, Not typeable 


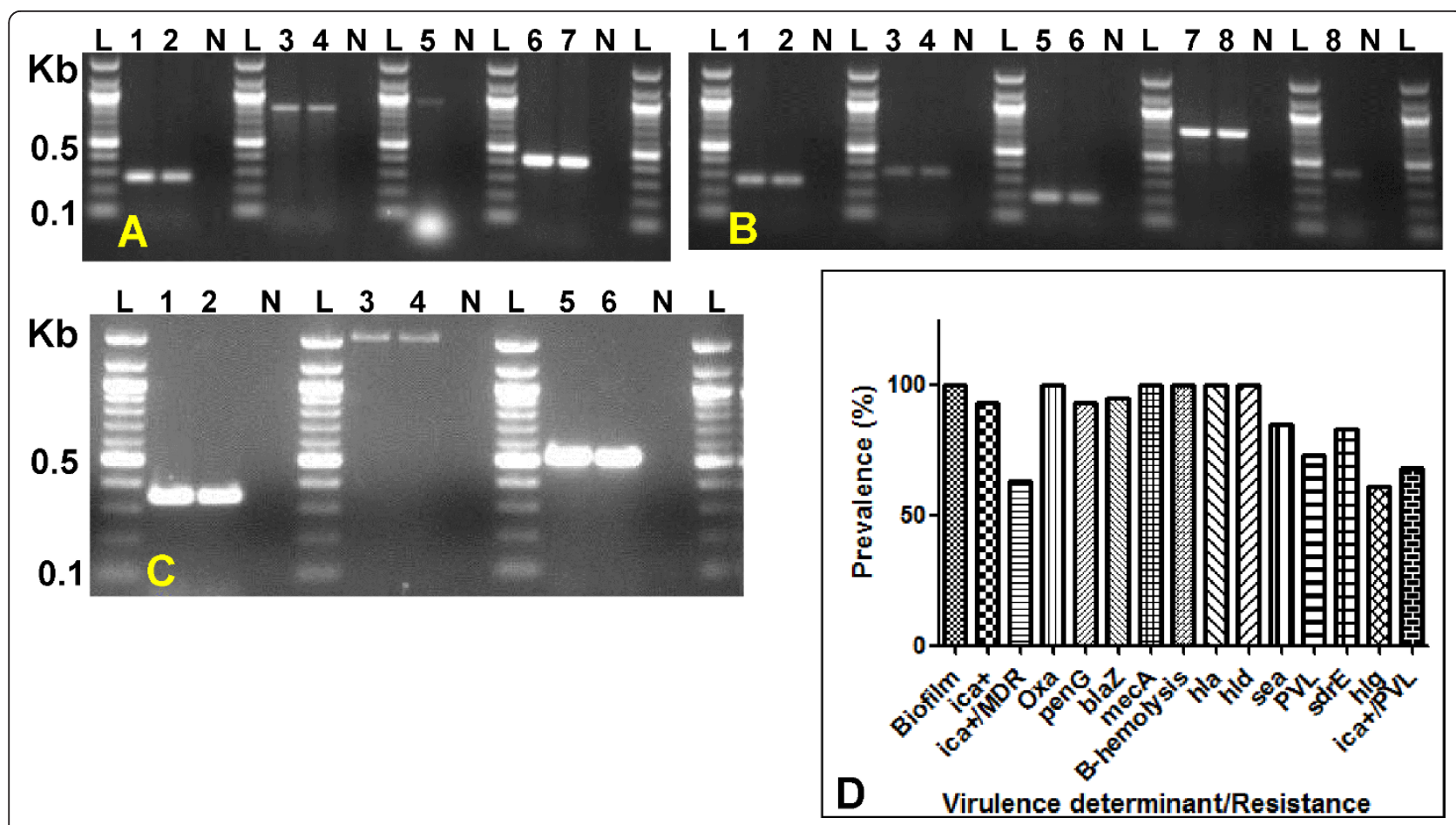

Figure 1 Representative images showing detection of virulence and antimicrobial resistance genes/determinants in MRSA isolates. Lanes: $L$, 100 bp DNA ladder; N, negative control (for all images). Panel A: 1 \& 2, species confirmation of $S$. aureus by detection of the nuc gene; 3 \& 4, ica; 5 , bhp; 6 \& 7, PVL. Panel B: 1 \& 2, nuc; 3 \& 4, tst1; 5 \& 6, hla; 7 \& 8, sdrE; 8, sea. Panel C: Detection of genes encoding aminoglycoside modifying enzymes (AMEs). 1 \& 2, (aac(6')-le-aph(2')-la); 3 \& 4, (aph(3')-IIIa); 5 \& 6, (ant(4')-la). Panel B. Graphical presentation of prevalence for selected determinants.

in this setting (i.e. $46 \%$ vs. $29 \%$ prevalence, respectively). Since all isolates were oxacillin resistant, $\operatorname{mec} A$-positive ( $m e c A$ encodes the penicillin binding protein $2 \mathrm{a}$, the molecular determinant for methicillin resistance [21]), $n u c$ - and femA-positive, they were confirmed as MRSA. Prior to use, the CHROMagar batch passed quality control screening with known MRSA and MSSA strains; yet only 26 isolates grew mauve colonies (which is indicative of MRSA); the use CHROMagar in this setting may need further investigations.

A high prevalence of biofilm/ica-positive isolates correlated with that of MDR isolates. Although biofilms/ica genes are debatable as virulence markers [22], in this study, the biofilm/ica-positive isolates were concomitantly positive for other virulence genes. Notably was the absolute prevalence for staphylococcal hemolysins: hla and $h l d$. The hla gene encodes a dermanecrotic and neurotoxic toxin that is also responsible for abscess formation; hld producing $S$. aureus can cause severe enteritis, while $h l g$ lyses mammalian red blood cells and together with tst-1 (toxic shock syndrome toxin-1), can be involved in the pathogenesis of toxic shock syndrome (TSS) [15]. PVL, also prevalent in this study, causes severe disease in children and young adults with no known exposure to healthcare establishment, and is used as a stable marker for community acquired MRSA [15].
Furthermore, the staphylococcal super-antigenic toxins, sea and tst-1 were also detected $(85 \%$ and $10 \%$ prevalence respectively). sea producing strains are responsible for staphylococcal food intoxications, while tst strains produce antigens that are responsible for TSS.

\section{Conclusion}

Hypervirulent methicillin resistant $S$. aureus is prevalent in the burns unit of Mulago hospital.

\section{Additional material}

Additional file 1: Primers and PCR conditions.

Additional file 2: Speciation, drug susceptibility testing and detection of virulence and antimicrobial resistance genes/

determinants. NA, Not applicable; ND, Not detected; MSSA, Methicillin Sensitive Staphylococcus aureus; MRSE, Methicillin Resistance Staphylococcus epidermidis.

\section{Abbreviations}

SCCmec: Staphylococcus Cassette Chromosomal mec; oxa: Oxacillin; penG: Penicillin G; SXT: Sulphamethoxazole-trimethopri; MDR: Multi Drug Resistant

\section{Acknowledgements}

This project was funded in part by Sida-Sarec (Sweden) to FCN through School of Graduate Studies, Makerere University. Additional support was sought from the National Institutes of Health grants \#R01 Al075637-02; 
HHSN266200700022C/NO1-Al-70022 and \# U2RTW006879. Gratitude to the staff and patients, Dept. of Surgery Mulago hospital; Geraldine Nalwadda, Betty Atuhaire and Joan Basemera (Dept of Medical Microbiology, MakCHS).

\section{Author details}

'Department of Medical Microbiology, School of Biomedical Sciences, Makerere University College of Health Sciences, Kampala, Uganda. ${ }^{2}$ Department of Veterinary Parasitology and Microbiology, School of Veterinary Medicine, Makerere University, Kampala, Uganda. ${ }^{3}$ Division of Plastic Surgery, Mulago National Referral and Teaching Hospital, Kampala, Uganda.

\section{Authors' contributions}

DPK, SN, MO, AO and FCN performed the molecular genetic studies. MLN, $R S, H B$ and $M L$ participated in the design of the study. FCN conceived the study, and participated in its design and coordination. DPK and FCN wrote the manuscript. All authors read and approved the final manuscript.

\section{Competing interests}

The authors declare that they have no competing interests.

Received: 1 April 2011 Accepted: 7 September 2011

Published: 7 September 2011

\section{References}

1. Wertheim HFL, Verbrugh HA: Global prevalence of meticillin-resistant Staphylococcus aureus. The Lancet 2006, 368(9550):1866.

2. Mugisa DB: Complications Following Laparotomy in Mulago Hospital. Master of Medicine (Surgery) Dissertation. Makerere University, Department of Surgery; 1988.

3. Olaro C: Risk factors for Postoperative Complication following abdominal Surgery in Mulago hospital. Master of Medicine (Surgery) Dissertation. Makerere University, Department of Surgery; 1999.

4. Ojikan-Odeke : Hand Infections in Uganda. Master of Medicine (Medical Microbiology) Dissertation. Makerere University, Department of Medical Microbiology; 1978.

5. Ojulong JMT, Joloba M, Bwanga F, Kaddu-Mulindwa DH: Relative prevalence of methicilline resistant Staphylococcus aureus and its susceptibility pattern in mulago hospital, Kampala, Uganda. Tanzanian Journal of Health Research 2009, 11(3):149-153.

6. Kateete D, Kimani C, Katabazi F, Okeng A, Okee M, Nanteza A, Joloba M, Najjuka F: Identification of Staphylococcus aureus: DNase and Mannitol salt agar improve the efficiency of the tube coagulase test. Annals of Clinical Microbiology and Antimicrobials 2010, 9(1):23.

7. Guideline for isolation precautions in hospitals: Part II. Recommendations for isolation precautions in hospitals. Hospital Infection Control Practices Advisory Committee. Am J Infect Control 1996, 24(1):32-52.

8. Boye $\mathrm{K}$, Bartels MD, Andersen IS, Møller JA, Westh $\mathrm{H}$ : A new multiplex PCR for easy screening of methicillin-resistant Staphylococcus aureus SCCmec types I-V. Clinical Microbiology and Infection 2007, 13(7):725-727.

9. Klingenberg C, Aarag E, Ronnestad A, Sollid JE, Abrahamsen TG, Kjeldsen G, Flaegstad T: Coagulase-negative staphylococcal sepsis in neonates. Association between antibiotic resistance, biofilm formation and the host inflammatory response. Pediatr Infect Dis J 2005, 24(9):817-822.

10. Amaral MM, Coelho LR, Flores RP, Souza RR, Silva-Carvalho MC, Teixeira LA, Ferreira-Carvalho BT, Figueiredo AM: The predominant variant of the Brazilian epidemic clonal complex of methicillin-resistant Staphylococcus aureus has an enhanced ability to produce biofilm and to adhere to and invade airway epithelial cells. J Infect Dis 2005, 192(5):801-810.

11. Kumar JD, Negi YK, Gaur A, Khanna D: Detection of virulence genes in Staphylococcus aureus isolated from paper currency. International Journal of Infectious Diseases 2009, 13(6)::450-e455.

12. Jarraud S, Mougel C, Thioulouse J, Lina G, Meugnier H, Forey F, Nesme X, Etienne J, Vandenesch F: Relationships between Staphylococcus aureus Genetic Background, Virulence Factors, agr Groups (Alleles), and Human Disease. Infect Immun 2002, 70(2):631-641.

13. McClure J-A, Conly JM, Lau V, Elsayed S, Louie T, Hutchins W, Zhang K: Novel Multiplex PCR Assay for Detection of the Staphylococcal Virulence Marker Panton-Valentine Leukocidin Genes and Simultaneous Discrimination of Methicillin-Susceptible from -Resistant Staphylococci. J Clin Microbiol 2006, 44(3):1141-1144.
14. Stotts SN: Virulence and Antibiotic Resistance Gene Combinations among Staphylococcus aureus Isolates from Coastal Waters of Oahu, Hawaii. The Journal of Young Investigators 2005, 12(4).

15. Cunha MLRS, Calsolari RAO: Toxigenicity in Staphylococcus aureus and Coagulase-Negative Staphylococci: Epidemiological and Molecular Aspects. Microbiology Insights 2008, 2008(MBI-1-Cunha-et-al).

16. Montanaro L, Campoccia D, Pirini V, Ravaioli S, Otto M, Arciola CR: Antibiotic multiresistance strictly associated with IS256 and ica genes in Staphylococcus epidermidis strains from implant orthopedic infections. J Biomed Mater Res A 2007, 83(3):813-818.

17. Verhoef J, Beaujean D, Blok H, Baars A, Meyler A, van der Werken C, Weersink A: A Dutch approach to methicillin-resistant Staphylococcus aureus. Eur J Clin Microbiol Infect Dis 1999, 18(7):461-466.

18. Vautor E, Abadie G, Pont A, Thiery R: Evaluation of the presence of the bap gene in Staphylococcus aureus isolates recovered from human and animals species. Vet Microbiol 2008, 127(3-4):407-411.

19. Shittu AO, Okon K, Adesida S, Oyedara O, Witte W, Strommenger B, Layer F, Nubel U: Antibiotic resistance and molecular epidemiology of Staphylococcus aureus in Nigeria. BMC Microbiol 2011, 11:92.

20. Perry JD, Davies A, Butterworth LA, Hopley ALJ, Nicholson A, Gould FK: Development and Evaluation of a Chromogenic Agar Medium for Methicillin-Resistant Staphylococcus aureus. I Clin Microbiol 2004, 42(10):4519-4523.

21. Mallorquí-Fernández G, Marrero A, García-Piquè S, García-Castellanos R, Gomis-Rüth F: Staphylococcal methicillin resistance: fine focus on folds and functions. FEMS Microbiology Letters 2004, 235(1):1-8.

22. Frank KL, Hanssen AD, Patel R: icaA Is Not a Useful Diagnostic Marker for Prosthetic Joint Infection. J Clin Microbiol 2004, 42(10):4846-4849.

doi:10.1186/1756-0500-4-326

Cite this article as: Kateete et al: High prevalence of methicillin resistant Staphylococcus aureus in the surgical units of Mulago hospital in Kampala, Uganda. BMC Research Notes 2011 4:326.

\section{Submit your next manuscript to BioMed Central and take full advantage of:}

- Convenient online submission

- Thorough peer review

- No space constraints or color figure charges

- Immediate publication on acceptance

- Inclusion in PubMed, CAS, Scopus and Google Scholar

- Research which is freely available for redistribution

Submit your manuscript at www.biomedcentral.com/submit
C BioMed Central 